\title{
Reguły wydatkowe dotyczące budżetu państwa (na gruncie ustawy o finansach publicznych z 2009 r.)
}

\section{Expenditure Rules Related to Government Budget (under the Public Finance Act 2009)}

Streszczenie. Artykuł poświęcony jest regułom wydatkowym dotyczącym budżetu państwa, określonym w ustawie o finansach publicznych. Przedmiotem analizy jest konstrukcja i funkcjonowanie reguł wydatkowych. Artykuł stanowi próbę odpowiedzi na pytanie o skuteczność tego rodzaju ograniczeń prowadzenia polityki budżetowej. Analizie poddano reguły określone w art. 112a-112d i art. 86 ustawy o finansach publicznych.

Słowa kluczowe: reguła wydatkowa, budżet państwa.

\begin{abstract}
The article is devoted to expenditure rules related to government budget, specified in Public Finance Act. The object of analysis is the legal construction and functioning of expenditure rules. The article tries to respond on a question of effectiveness of these restrictions of conduct of budgetary policy. The analysis covers the rules in articles 112a-112d and 86 of Public Finance Act.
\end{abstract}


Keywords: expenditure rule; government budget.

\section{Uwagi wstępne. Cel opracowania}

Reguły fiskalne, wprowadzone jak dotąd w wielu krajach, postrzegane są jako obiecujące narzędzie $\mathrm{w}$ walce $\mathrm{z}$ kryzysem finansów publicznych. Przyczyną wprowadzania reguł fiskalnych do systemów finansów publicznych jest konieczność zaradzenia zjawisku nadmiernego zadłużenia państw oraz związanego z nim nadmiernego deficytu publicznego ${ }^{1}$.

Istotą reguł fiskalnych jest trwałe ograniczenie uznaniowości w prowadzeniu polityki budżetowej ${ }^{2}$. Wyróżnić można wiele rodzajów reguł fiskalnych, m.in. reguły numeryczne (ilościowe) i jakościowe (opisowe). Reguły numeryczne polegają na ustanowieniu limitów dla wskaźników budżetowych ${ }^{3}$.

Wyróżnia się cztery podstawowe rodzaje reguł fiskalnych ${ }^{4}$ :

1. Reguły zrównoważonego budżetu - odnoszące się do salda budżetu,

2. Reguły długu - ustanawiające limity zadłużenia,

3. Reguły wydatkowe - limitujące poziom wydatków,

4. Reguły dochodowe - limitujące poziom dochodów państwa.

Wskazuje się przy tym na wysoką skuteczność reguł wydatkowych w realizacji celów polityki budżetowej ${ }^{5}$.

Zauważa się, że skuteczność reguł fiskalnych zależy głównie od ich konstrukcji, która powinna być prosta i obejmować w miarę możliwości cały sektor finansów publicznych, oraz od ich wiarygodności. Ten drugi element wyraża trwałość reguły oraz skłonność rządzących do jej prze-

\footnotetext{
K. Marchewka-Bartkowiak, Zarzqdzanie długiem Skarbu Państwa. Implikacje dla strefy euro, Warszawa 2011, s. 44-49.

2 J. Kantorowicz, Reguły fiskalne - co się sprawdza?, [w:] Analiza FOR nr 3/2012, s. 4, [za:] G. Kopits, S. Symansky, Fiscal Policy Rules, IMF Occasional Paper 162/1998, http://www.for.org.pl/pl/a/2067,Analiza-32012-Reguly-fiskalne-co-sie-sprawdza (dostęp: 13 września 2013 r.).

K. Marchewka-Bartkowiak, Zarzqdzanie długiem..., s. 47.

J. Kantorowicz, Reguły fiskalne..., s. 5.

Tamże, s. 6.
} 
strzegania. Kryterium wiarygodności reguły wiąże się więc m.in. z jej formalizacją, czyli z nadaniem jej charakteru normatywnego ${ }^{6}$.

Sformalizowane reguły fiskalne mają więc postać norm prawnych zawierających ograniczenia dotyczące swobody Rady Ministrów w prowadzeniu polityki budżetowej. Mogą być powiązane z wystąpieniem określonego warunku (np. wysokością państwowego długu publicznego), a także zawierać wyjątki od stosowania reguły (np. stany nadzwyczajne, wydatki niepodlegające regule) i klauzule wyjścia ${ }^{7}$.

Obecnie można wskazać na istnienie w Polsce reguł fiskalnych dotyczących państwowego długu publicznego (reguła ta zawarta jest w art. 216 ust. 5 Konstytucji $^{8}$ ) oraz m.in. reguł wydatkowych dotyczących budżetu państwa, zawartych w ustawie z dnia 27 sierpnia 2009 r. o finansach publicznych $^{9}$.

Celem artykułu jest analiza reguł wydatkowych odnoszących się do budżetu państwa zawartych w ustawie z dnia 27 sierpnia 2009 r. o finansach publicznych, zwłaszcza w art. 112a-112d i art. 86. Przedmiotem rozważań jest charakter prawny reguł oraz ich funkcjonowanie w praktyce.

\section{Reguły wydatkowe w art. 112a-112d i w art. 86 ustawy z 2009 r. o finansach publicznych}

W projekcie ustawy o finansach publicznych proponowano wprowadzenie reguły ograniczającej tempo wzrostu wydatków niektórych podmiotów wymienionych w art. 139 ust. 2 u.f.p. (m.in. Krajowa Rada Sądownictwa,

Tamże, s. 2, 7.

Klauzula wyjścia oznacza możliwość legalnego odstąpienia od stosowania reguły, np. w Szwajcarii Parlament może większością 2/3 głosów uchwalić budżet niezgodny z regułą w przypadku „wyjątkowych okoliczności”. J. Kantorowicz, Reguły fiskalne..., s. 13.

8 Konstytucja Rzeczypospolitej Polskiej z dnia 2 kwietnia 1997 r. (Dz.U. Nr 78, poz. 483 ze zm.).

$9 \quad$ Tekst jedn. Dz.U. z 2013 r., poz. 885 ze zm., dalej: u.f.p. Ponadto są też reguły dotyczące budżetu jednostek samorządu terytorialnego - np. ograniczenia z art. 242-244 u.f.p. 
Rzecznik Praw Obywatelskich i inne), która jednak ostatecznie nie znalazła akceptacji ustawodawcy ${ }^{10}$.

Obecnie ustawa o finansach publicznych przewiduje reguły odnoszące się do wydatków budżetu państwa w art. 112a-112d oraz w art. 86.

Reguła z art. 112a-112d, określana jako tzw. tymczasowa lub dyscyplinująca reguła wydatkowa, została dodana do u.f.p. w 2010 r. ${ }^{11}$ Weszła ona w życie 1 stycznia 2011 r. Reguła ta polega na ograniczeniu tempa wzrostu niektórych wydatków budżetu państwa. Ma ona charakter bezpośredni, odnosi się ona wprost do wydatków budżetu państwa.

Zgodnie z regułą, kwota wydatków budżetu państwa na zadania publiczne nie może być większa niż kwota środków planowanych na ich realizację w roku poprzednim powiększona o wartość inflacji prognozowaną na dany rok budżetowy, przyjętą w założeniach do projektu ustawy budżetowej, powiększoną o jeden punkt procentowy (art. 112a).

Z ograniczenia tego wyłączone zostały niektóre wydatki, wskazane w sposób wyczerpujący w art. 112a ust. 2. Są to m.in. wydatki na obsługę długu publicznego, środki własne Unii Europejskiej, wydatki na realizację programów finansowanych z udziałem środków z budżetu UE, świadczenia rodzinne, uposażenia sędziów i prokuratorów w stanie spoczynku, świadczenia emerytalno-rentowe funkcjonariuszy, dotacja do Funduszu Ubezpieczeń Społecznych, Funduszu Emerytur Pomostowych i Funduszu Emerytalno-Rentowego na sfinansowanie wypłat świadczeń emerytalnorentowych gwarantowanych przez państwo.

Wydatki wyłączone spod reguły są wydatkami prawnie zdeterminowanymi, sztywnymi. Państwo nie ma wpływu na ich wysokość, gdyż wynikają one z przyjętych wcześniej zobowiązań wobec osób trzecich. Za element reguły należałoby uznać także art. 112c, zgodnie z którym w okresie stosowania reguły RM nie może przyjmować projektów ustaw zmniejszających dochody budżetu państwa ani zwiększających wydatki niepodlegające regule wydatkowej (wymienione w przytoczonym powy-

Art. 130 projektu ustawy o finansach publicznych, druk sejmowy nr 1181.

Ustawa z dnia 16 grudnia 2010 r. o zmianie ustawy o finansach publicznych oraz niektórych innych ustaw (Dz.U. Nr 257, poz. 1726 ze zm.). 
żej art. 112a ust. 2). Przepis ten ma zapobiegać powstawaniu nowych wydatków prawnie zdeterminowanych ${ }^{12}$.

Wskazuje się, że wydatki sztywne, niepodlegające regule, stanowią ok. 80\% wydatków budżetu państwa. Ogranicza to skuteczność stosowania reguły, która obejmuje w praktyce jedynie ok. 20\% wydatków budże$\mathrm{tu}^{13}$.

Reguła z 2010 r. określana jest jako tymczasowa z uwagi na jej ograniczone zastosowanie. Związane jest ono ściśle z unijną procedurą nadmiernego deficytu, w ramach której do państwa członkowskiego dopuszczającego do nadmiernego deficytu, kierowane są zalecenia. Regułę wydatkową stosuje się do opracowania Wieloletniego Planu Finansowego Państwa i przygotowania projektu ustawy budżetowej, w okresie od dnia skierowania do Rzeczypospolitej Polskiej takich zaleceń do dnia ich uchylenia. Polska od momentu przystąpienia do UE objęta jest procedurą nadmiernego deficytu niemal nieprzerwanie od 2004 r. do chwili obecnej ${ }^{14}$.

Reguły nie stosuje się w przypadku wprowadzenia stanów nadzwyczajnych. W 2013 r. do u.f.p. dodano art. 112e, zawieszający stosowanie reguły tymczasowej w 2013 r. $^{15}$

W lipcu 2013 r. RM przedstawiła projekt założeń do projektu ustawy zmieniającej ustawę o finansach publicznych, w którym przewidziano nową regułę wydatkową, określaną mianem stabilizującej, która ma zastąpić regułę dyscyplinującą z 2010 r. ${ }^{16}$ Wprowadzenie nowej reguły ma

12 Uzasadnienie do projektu ustawy z dnia 16 grudnia 2010 r. o zmianie ustawy o finansach publicznych oraz niektórych innych ustaw, druk sejmowy nr 3576, s. 4.

13 T.M. Budzyński, Opinia o ustawie o zmianie ustawy o finansach publicznych oraz niektórych innych ustaw, (druk senacki nr 1062), Opinie i Ekspertyzy OE-159, grudzień 2010, s. 8, http://ww2.senat.pl/k7/dok/opinia/2010/oe-159.pdf (dostęp: 19 września 2013 r.).

14 W latach 2004-2008 i od roku 2009 do chwili obecnej. Uzasadnienie do projektu ustawy o zmianie ustawy o finansach publicznych oraz niektórych innych ustaw, s. 2, druk sejmowy nr 1789, http://orka.sejm.gov.pl/Druki7ka.nsf/0/0A202835B8528121C1257BF900515C8F/\%24File/1789.pdf (dostęp: 17 października 2013 r.).

15 Ustawa z dnia 26 lipca 2013 r. (Dz.U. poz. 938). Zmiana weszła w życie z dniem 20 sierpnia $2013 \mathrm{r}$.

16 Założenia do projektu ustawy o zmianie ustawy o finansach publicznych, http://legislacja.rcl.gov.pl/docs//1/165461/165493/165494/dokument80762.pdf s. 4, (dostęp: 27 września 2013 r.). 
wypełniać wymóg Dyrektywy Rady nr 2011/85/UE z dnia 8 listopada 2011 r. w sprawie wymogów dla ram budżetowych państw członkowskich $^{17}$.

Projektowana reguła stabilizująca ma być, w przeciwieństwie do obecnie obowiązującej, regułą antycykliczną. Jej funkcjonowanie ma uwzględniać wpływ cyklu koniunkturalnego w gospodarce na wysokość wydatków budżetu państwa. Mechanizm obliczania reguły będzie uwzględniał wzór matematyczny uwzględniający liczne elementy takie jak: wysokość wydatków w poprzednim roku, inflacja wraz z korektą czy PKB w latach ubiegłych, ponadto ma uwzględniać również wahania cyklu gospodarczego.

Nowa reguła ma mieć szerszy zakres niż reguła tymczasowa. Zgodnie z projektem regułą mają być objęte obok budżetu państwa m.in. fundusze zarządzane przez BGK, Fundusz Ubezpieczeń Społecznych i in. Regułą mają być objęte także jednostki samorządu terytorialnego, Narodowy Fundusz Zdrowia i podmioty z art. 139 ust. 2 u.f.p. z tym, że w przypadku wymienionych wyżej podmiotów (j.s.t., NFZ i podmioty z art. 139 ust. 2 u.f.p.) objęcie regułą oznacza, że ich prognozowane wydatki i koszty będą odejmowane od kwoty wydatków podlegających regule. $\mathrm{Z}$ reguły wyłączone mają być natomiast m.in. uczelnie publiczne, samorządowe zakłady budżetowe, agencje wykonawcze, instytucje gospodarki budżetowej, instytucje kultury oraz inne państwowe i samorządowe osoby prawne ${ }^{18}$. W kwocie wydatków obliczanych zgodnie $\mathrm{z}$ regułą nie mają być uwzględniane wydatki budżetu środków europejskich, wydatki finansowane środkami z budżetu UE lub państw EFTA oraz dotacje i subwencje dla j.s.t.

Po uwzględnieniu wydatków wskazanych wyżej podmiotów i typów, pozostała kwota wydatków obliczona zgodnie z treścią projektowanych zmian ujętych w ramach wzoru matematycznego stanowić ma nieprzekraczalny limit dla organów opracowujących projekt budżetu.

17 Uzasadnienie do projektu ustawy o zmianie ustawy o finansach publicznych oraz niektórych innych ustaw, druk sejmowy nr 1789, s. 3.

Tamże, s. 8-9. 
Reguła z art. 86 u.f.p. ustanawia progi ostrożnościowe, związane z poziomem państwowego długu publicznego w stosunku do PKB. Odnosi się ona nie tylko do budżetu państwa, ale także do jednostek samorządu terytorialnego i całego sektora finansów publicznych. Reguła ta w sposób pośredni dotyczy wydatków budżetu państwa.

Mechanizm reguły z art. 86 u.f.p. polega na ograniczaniu wzrostu wydatków budżetu państwa w sytuacji przekroczenia przez państwowy dług publiczny określonego poziomu w stosunku do PKB (analogiczne rozwiązanie funkcjonowało już pod rządami poprzednich ustaw o finansach publicznych). W art. 86 u.f.p. przewidziano trzy progi relacji państwowego długu publicznego do PKB: od 50 do 55\% włącznie, powyżej 55 do mniej niż 60\% oraz 60\% PKB i powyżej. Z osiągnięciem przez państwowy dług publiczny powyższych poziomów w stosunku do PKB wiąże się uruchamianie kolejnych ograniczeń, m.in. wysokości planowanych wydatków budżetu państwa.

Gdy wartość relacji kwoty państwowego długu publicznego do PKB jest większa od 50\%, a nie większa od 55\%, na kolejny rok RM powinna uchwalić projekt ustawy budżetowej, w którym relacja deficytu budżetu państwa do dochodów budżetu państwa nie może być wyższa niż analogiczna relacja z roku bieżącego wynikająca z ustawy budżetowej. Przekroczenie przez państwowy dług publiczny 55\% PKB powoduje uruchomienie kolejnych ograniczeń dotyczących planowania wydatków budżetu państwa, a w dalszej kolejności także budżetów samorządów oraz innych jednostek sektora finansów publicznych.

Reguły wydatkowe wyrażone są w przepisach rangi ustawowej, są więc obowiązującym prawem, do którego przestrzegania zobligowane są organy odpowiedzialne za opracowanie projektu ustawy budżetowej. Reguły wydatkowe należy traktować jako prawne granice planowania wydatków budżetowych, na równi z innymi regulacjami u.f.p. dotyczącymi planowania wydatków.

Charakter prawny reguł wydatkowych jest więc odmienny od np. charakteru prawnego Wieloletniego Planu Finansowego Państwa. Ustalenia WPFP, mimo że również prawnie „wiążące”, nie determinują jednak 
treści ustawy budżetowej, która może przyjąć inne wartości dochodów i wydatków, niż przewidziane w planie.

Nie ma usprawiedliwienia dla niezastosowania się do reguł w sytuacji, gdy stan finansów państwa jest zły i stosowanie się do reguł jest trudne. Przyjęcie innego stanowiska prowadziłoby do zakwestionowania znaczenia reguł, skoro można byłoby je po prostu pominąć. Odstąpienie od stosowania się do reguły mogłoby nastąpić jedynie w sytuacji, gdy ona sama przewiduje taką możliwość poprzez stosowną klauzulę. Należałoby zastanowić się nad istotą działania mechanizmu reguł i przyczyną, dla których są one ustanawiane.

Obecnie reguły wydatkowe uruchamiane są w przypadku spełnienia się określonego warunku ${ }^{19}$. Warunkiem tym może być osiągnięcie przez państwowy dług publiczny określonego poziomu (art. 86 u.f.p.) lub skierowanie do Polski zaleceń w związku z procedurą nadmiernego deficytu (art. 112b u.f.p.). Spełnienie się warunku odzwierciedla istnienie określonego problemu w finansach państwa. Można dostrzec, że obecnie wprowadzanie reguł wydatkowych jest traktowane w kategoriach reformowania finansów publicznych, stanowi próbę odpowiedzi na kryzys gospodarczy. Może wynikać z tego uzależnianie przez ustawodawcę ich zastosowania od spełnienia danego warunku. Gdy sytuacja finansowa państwa jest dobra, tego rodzaju ograniczenia w kreowaniu polityki budżetowej w zasadzie nie są potrzebne, choć, oczywiście, mogą być ustanawiane. Ziszczenie się warunku lub pogorszenie sytuacji finansowej państwa stanowi więc rzeczywisty sprawdzian dla skuteczności reguły. Zasadniczy sens reguł wydatkowych tkwi zatem w tym, że gdy spełniony zostaje określony warunek lub kontynuowanie dotychczasowej polityki budżetowej jest niemożliwe, RM musi podjąć działania mające na celu wypełnienie dyspozycji reguły. Reguła ma wymusić podjęcie przez RM odpowiednich działań, aby z jednej strony skonstruować możliwy do wykonania budżet, zapewniający finansowanie licznych zadań państwa, a z drugiej strony nie przekroczyć określonego poziomu wydatków. Można to osiągnąć w dłuższej perspektywie przez dokonywanie rzeczywistych reform,

19 Jednak wydaje się, że istnienie warunku nie musi być obowiązkowym elementem konstrukcyjnym reguły fiskalnej. 
skutkujących poprawą finansów państwa, dokonanie oszczędności itp. dających poprawę w dłuższym okresie. Czy jednak istnienie reguły naprawdę jest w stanie zmusić władze wykonawcze do podjęcia reform, czy reguły mają taką moc jedynie $\mathrm{w}$ teorii?

\section{Czy reguły wydatkowe są stosowane?}

Z dokumentów towarzyszących projektowi zmiany u.f.p. wynika, że same organy władzy wykonawczej uważają się za związane bezwzględnie treścią reguł i deklarują ich przestrzeganie obowiązkowo, gdy wejdą w życie, lub jedynie pomocniczo, do czasu ich wejścia w życie ${ }^{20}$. Jednak rzeczywisty stosunek organów władzy wykonawczej do kłopotliwych niekiedy regulacji wyrażają nie tylko deklaracje, ale inne podejmowane działania.

W praktyce reguły wydatkowe mogą podlegać różnym prawnym zabiegom zmniejszającym ich oddziaływanie. Organy władzy wykonawczej mogą przestrzegać reguł, poprzez „obchodzenie” prawa. Wskazać można tu na zjawiska takie, jak: kreatywna księgowość, „wypychanie” długu poza sektor finansów publicznych, korzystanie z bezzwrotnych źródeł przychodów zapewniające zachowanie relacji państwowego długu publicznego do PKB i inne działania, dzięki którym wskaźniki dochodów, wydatków i długu pozostają nieprzekroczone ${ }^{21}$. W takim przypadku mamy do czynienia z czysto formalnym i pozornym przestrzeganiem reguł. Nie towarzyszy im jednak poprawa stanu finansów publicznych w dłuższym okresie, a wręcz stan ten może się pogorszyć (np. wskutek wyczerpania się ww. możliwości „obchodzenia” reguł).

Przykładem możliwego negatywnego oddziaływania reguł na finanse państwa jest art. 86 ust. 1 pkt. 2 u.f.p. Przepis ten dotyczy sytuacji, gdy państwowy dług publiczny mieści się w przedziale 55-60\% PKB. Pozwala on na zwiększanie deficytu budżetu państwa pod warunkiem, że relacja długu Skarbu Państwa do PKB będzie niższa w przyszłym roku budżeto-

20 Założenia do projektu ustawy..., s. 4.

21 K. Marchewka-Bartkowiak, Reguły fiskalne, „Analizy BAS” 2010, nr 7, s. 3; J. Kantorowicz, Reguły fiskalne..., s. 7. 
wym w stosunku do analogicznej relacji w roku bieżącym. Aby to osiągnąć, deficyt budżetu państwa musiałby być pokrywany ze źródeł innych, niż zwrotne źródła przychodów. Takim źródłem mogłyby być przychody z prywatyzacji majątku. W ten sposób art. 86 ust. 1 pkt. 2 u.f.p. może być potencjalnie szkodliwy dla interesów rządu, bo po wyczerpaniu możliwości zaciągania kredytów i pożyczek skłaniać może nie do poszukiwania możliwości zredukowania wydatków lub zwiększenia dochodów, ale do pozbywania się majątku państwowego.

Inna możliwość wiąże się z modyfikacją przepisów ustanawiających reguły. $\mathrm{W}$ wypadku, gdy $\mathrm{z}$ jakichś powodów nie jest możliwe spełnienie dyspozycji reguł, można wyobrazić sobie sytuację, w której reguły są modyfikowane lub usuwane z ustawodawstwa. W ten sposób dochodzi do „rozbrojenia” kłopotliwych przepisów, które, podobnie jak w pierwszym przypadku, zostają zredukowane do „ozdobnika” sprawiającego pozory istnienia mechanizmów zabezpieczających finanse państwa.

Przykładem powyższych działań jest art. 86 ust. 1 pkt. 1 u.f.p. Przepis ten ustanawia pierwszy z progów ostrożnościowych (państwowy dług publiczny w przedziale 50-55\% PKB). Zgodnie z jego treścią, w takiej sytuacji RM powinna na kolejny rok budżetowy przyjąć projekt ustawy budżetowej, w którym relacja deficytu do dochodów budżetu państwa nie byłaby wyższa, niż analogiczna relacja w roku bieżącym. Jednak w wyniku nowelizacji u.f.p. z dnia 26 lipca 2013 r. $^{22}$, która weszła w życie już 20 sierpnia tego samego roku, stosowanie art. 86 ust. 1 pkt. 1 ustawy zostało zawieszone w roku 2013, co oznacza, że RM, planując budżet na rok 2014, nie ma obowiązku ograniczenia wysokości deficytu budżetowego ${ }^{23}$.

Na samym zawieszeniu omawianej regulacji może się nie skończyć, gdyż zgodnie z projektem nowelizacji u.f.p. (druk sejmowy nr 1789, art. 1

22 Tą samą ustawą wyłączono stosowanie w 2013 r. art. 112a i 112b, dodając do niej stosowny art. 112e. Zawieszenie stosowania artykułów: 86 ust. 1 pkt. 1, 112a i 112b u.f.p. w 2013 r. było jedyną treścią ustawy z dnia 26 lipca 2013 r.

23 Zgodnie z obwieszczeniem Ministra Finansów z dnia 21 maja 2013 r. (M.P. poz. 459), relacja państwowego długu publicznego do PKB na koniec 2012 r. wyniosła 52,7\%, a relacja kwoty państwowego długu publicznego do PKB obliczona zgodnie $\mathrm{z}$ art. 38a pkt 4 u.f.p. wyniosła 51,3\%, co uzasadniało obowiązek zastosowania art. 86 ust. 1 pkt. 1 u.f.p. do opracowania projektu ustawy budżetowej na 2014 r. 
pkt. 4 projektu), pierwszy z progów ostrożnościowych i sanacyjnych ma zostać zniesiony. Zgodnie z projektem uchylony ma być punkt 1) artykułu 86 ustęp 1 u.f.p. (w którym ustanowiono próg 50-55\% PKB). Oznacza to, że w przypadku uchwalenia nowelizacji u.f.p. w planowanym brzmieniu, przekroczenie przez państwowy dług publiczny wartości 50\% PKB nie będzie zobowiązywało RM do limitowania deficytu w projekcie ustawy budżetowej nie tylko w 2014 r., ale także w kolejnych latach.

W ustawie budżetowej na 2013 r. $^{24}$ zaplanowano dochody budżetu państwa na kwotę ok. 299,3 mld zł. Deficyt budżetu państwa miał wynieść ok. 35,5 mld zł (obecnie zaplanowane jest jednak jego zwiększenie do 51,5 mld zł przy jednoczesnym zmniejszeniu dochodów do 275,7 mld $\mathrm{zl}^{25}$ ). Z kolei w projekcie ustawy budżetowej na $2014 \mathrm{r}^{26}{ }^{2}$ zaplanowano dochody budżetu państwa w wysokości 276,9 mld zł, a deficyt budżetu państwa w wysokości 47,7 mld zł.

Ustawa zmieniająca ustawę budżetową została uchwalona przez Sejm 27 września 2013 r. Uchwalenie tej ustawy - zwiększającej relację deficytu do dochodów budżetu państwa - nastąpiło już po 20 sierpnia 2013 r., kiedy to weszło w życie zawieszenie pierwszego progu ostrożnościowego. Można postawić pytanie, czy gdyby art. 86 ust. 1 pkt. 1 u.f.p. nie miał zostać zawieszony lub uchylony, możliwe byłoby utrzymanie relacji deficytu budżetu państwa do dochodów w roku budżetowym 2013, a także, czy możliwe byłoby zaplanowanie właściwej relacji deficytu do dochodów w roku 2014.

W wersji pierwotnej ustawy budżetowej na 2013 r. relacja deficytu do dochodów wynosi (w przybliżeniu) 11,8\%. W wersji po poprawce relacja wynosi już 18,6\%. Natomiast relacja zaplanowana w projekcie na 2014 r. wynosi 17,2\%. Widoczne jest, że planowana na 2014 r. relacja deficytu budżetu państwa do dochodów przekracza relację z pierwotnej wersji ustawy budżetowej na rok 2013.

24 Ustawa budżetowa na rok 2013 (Dz.U. poz. 169).

25 Ustawa z dnia 27 września 2013 r. o zmianie ustawy budżetowej na rok 2013 (Dz.U. poz. 1212).

26 Druk sejmowy nr 1779. 
Podany przypadek wskazuje, że bez zawieszenia art. 86 ust. 1 pkt. 1 problematyczna byłaby możliwość tak znacznego zwiększenia wysokości deficytu w trakcie roku budżetowego, skutkująca wyraźnym zwiększeniem relacji deficytu do dochodów, ponad limit wynikający z art. 86 ust. 1 pkt. 1. Przestrzeganie relacji deficytu do dochodów budżetu jest obligatoryjne (omawiany przepis wyraźnie mówi, że RM „uchwala” projekt z właściwą relacją). Na marginesie należy zauważyć, że nie sprecyzowano jednak, czy art. 86 ust. 1 pkt. 1 odnosi się jedynie do projektu właściwej ustawy budżetowej, czy obejmuje również ewentualne nowelizacje, ale wydaje się, że należy przyjąć tę drugą możliwość ${ }^{27}$.

Podany przykład wskazuje, że zawieszenie (a w przyszłości być może uchylenie) pierwszego progu procedur ostrożnościowych i sanacyjnych było konieczne, aby planować zwiększenie deficytu budżetu państwa.

W uzasadnieniu do projektu ustawy zawieszającej pierwszy próg ostrożnościowy stwierdzono, że przepis ten (podobnie jak reguła tymczasowa) spełnił już swoją rolę, zabezpieczając finanse państwa w poprzednich latach. Zniesienie progu usprawiedliwione jest faktem, że obowiązek utrzymania relacji deficytu do dochodów powoduje konieczność redukcji wydatków, co nie jest korzystne w warunkach kryzysu gospodarczego (procykliczne oddziaływanie zredukowanych wydatków budżetowych) ${ }^{28}$.

Szczególnie kontrowersyjną sytuacją byłoby niewypełnienie dyspozycji reguły wydatkowej (nawet pod względem czysto formalnym) przy pozostawieniu jej w systemie prawnym. Nie sposób zaakceptować sytuacji, w której organy władzy rządowej mogłyby dopuścić do przyjęcia

27 Gdyby bowiem uznać, że art. 86 ust. 1 pkt. 1 nie odnosi się do nowelizacji ustaw budżetowych, możliwe byłoby jego „omijanie”. W sytuacji, gdy państwowy dług publiczny kształtowałby się w przedziale 50-55\% PKB, wystarczyłoby uchwalić na przyszły rok ustawę budżetową z odpowiednią relacją deficytu do dochodów, a następnie w trakcie roku budżetowego dokonać jej nowelizacji, zmieniając wysokość wskaźników budżetowych i tworząc nową relację deficytu do dochodów. Następnie ta nowa relacja mogłaby stanowić podstawę projektu ustawy budżetowej na kolejny rok budżetowy. Jednak możliwość taka wyczerpałaby się w sytuacji, gdy nawet przy bardzo optymistycznym oszacowaniu wysokości wskaźników budżetowych nie byłoby możliwe zachowanie relacji deficytu do dochodów w projekcie ustawy budżetowej.

28 Uzasadnienie do projektu ustawy z dnia 26 lipca 2013 r. o zmianie ustawy o finansach publicznych, druk sejmowy nr 1575, s. 1 i n. 
projektu aktu prawnego niezgodnego $\mathrm{z}$ ustawą. $\mathrm{W}$ tym miejscu należy jednak postawić pytanie, do kogo skierowane są normy ustawy o finansach publicznych przewidujące reguły wydatkowe. Należy uznać, że skierowane są one do dysponentów części budżetowych i organów rządu opracowujących projekt ustawy budżetowej.

Natomiast inną kwestią jest to, czy przepisy te musi uwzględniać Sejm. Z pewnością Sejm podczas prac legislacyjnych nad projektem ustawy budżetowej jest zobowiązany przestrzegać Konstytucji, zwłaszcza art. 220, zgodnie z którym zwiększenie wydatków lub ograniczenie dochodów planowanych przez RM nie może powodować ustalenia przez Sejm większego deficytu budżetowego niż przewidziany w projekcie ustawy budżetowej. Dyskusyjne jest natomiast to, czy Sejmu dotyczy obowiązek przestrzegania reguł wydatkowych określonych w ustawie o finansach publicznych. Wydaje się, że możliwa byłaby zmiana projektu ustawy budżetowej w trakcie prac legislacyjnych, przekraczająca limity wynikające z reguł wydatkowych zwłaszcza, gdyby w grę wchodziło naruszenie ustaw dotyczących wydatków sztywnych. Projekt ustawy budżetowej przedłożony Sejmowi jest kierowany na ręce Marszałka Sejmu, który nadaje bieg inicjatywom ustawodawczym po zasięgnięciu opinii Prezydium Sejmu. W przypadku wątpliwości co do zgodności projektu z prawem polskim lub prawem UE Marszałek Sejmu, po zasięgnięciu opinii Prezydium Sejmu, może skierować projekt do Komisji Ustawodawczej celem wyrażenia opinii. Projektowi zaopiniowanemu przez KU jako niedopuszczalny Marszałek Sejmu może nie nadać dalszego biegu ${ }^{29}$.

Co do zasady, jeśli projekt taki trafiłby pod obrady Sejmu, powinien zostać odpowiednio zmieniony $\mathrm{w}$ trakcie prac legislacyjnych $\mathrm{w}$ celu przywrócenia zgodności z prawem. Gdyby została uchwalona ustawa niezgodna z prawem, mogłaby być ona wykluczona z porządku prawnego przez Trybunał Konstytucyjny w przypadku złożenia wniosku o zbadanie jej zgodności z Konstytucją.

Jeżeli jednak nie doszłoby do badania takiej ustawy przez TK wydaje się, że przyjęte w niej limity wydatków byłyby wiążące dla organów wy-

29 Art. 10 i art. 34 ust. 8 Regulaminu Sejmu. 
konujących budżet. Zgodnie z art. 52 u.f.p. ujęte w budżecie państwa wydatki stanowią nieprzekraczalny limit. Przepis ten jest adresowany do organów wykonujących budżet państwa. Ustalona w ustawie budżetowej wysokość wydatków jest dla nich wiążąca bez względu na to, czy została wyliczona zgodnie z regułą wydatkową.

Niewypełnieniu dyspozycji reguł wydatkowych w przypadku budżetu państwa mogą towarzyszyć sankcje prawne związane z odpowiedzialnością konstytucyjną przed Trybunałem Stanu oraz odpowiedzialnością polityczną przed Sejmem. Mogą im także towarzyszyć silne sankcje pozaprawne, np. koszty polityczne, spadek zaufania rynków finansowych, utrata poparcia społecznego itp.

Szczególna sytuacja miałaby miejsce, gdyby nie dałoby się skonstruować budżetu bez przekroczenia limitów narzuconych przez reguły wydatkowe. Sytuacja taka może wystąpić w praktyce. Obecnie dotyczy ona jednostek samorządu terytorialnego, czego dowodzi projekt nowelizacji u.f.p. przewidujący tryb postępowania w przypadku braku możliwości uchwalenia budżetu j.s.t. z uwzględnieniem zasad zawartych w art. 242244 u.f.p. W projekcie dopuszcza się w takiej sytuacji nieprzestrzeganie wymogów z art. 242-244 u.f.p. (art. 1 pkt. 20 projektu ${ }^{30}$ ). Sam fakt wprowadzenia tego rodzaju klauzuli wyjścia świadczy o tym, że możliwość stosowania reguł z art. 242-244 u.f.p. się wyczerpuje w systemie samorządowym i mają miejsce sytuacje związane z niewykonalnością reguł fiskalnych.

Skuteczna reguła wydatkowa musi być wykonalna. Nie może ona uniemożliwiać skonstruowania budżetu. Istnieje ryzyko, że w coraz trudniejszej sytuacji finansowej państwa reguły mogłyby być nierealne. Czy w takim przypadku, gdyby nie zawierały one żadnych klauzul pozwalających na ich niestosowanie, możliwe byłoby odstąpienie od ich przestrzegania?

Organy władzy rządowej mają możliwość modyfikacji reguł np. poprzez wprowadzanie do nich odpowiednich klauzul lub nawet wnioskowanie o ich usunięcie. Można wyobrazić sobie uchwalenie budżetu bez

30 Druk sejmowy nr 1789. 
stosowania się do reguł w sytuacji, gdy nie ma innej możliwości zaplanowania dochodów i wydatków, a usunięcie reguły jest niemożliwe z przyczyn politycznych, np. stosowna ustawa nie ma szans na przegłosowanie. Byłaby to jednak niekorzystna sytuacja, będąca wyrazem naruszenia prawa i podważająca wiarygodność państwa, przynosząca poważne straty polityczne i wizerunkowe, która może skutkować odpowiedzialnością konstytucyjną i polityczną osób, które dopuściły się naruszenia.

\section{Podsumowanie}

Obserwacja dotychczasowego funkcjonowania reguł wydatkowych skłaniać może do wniosku, że nie spełniają one należycie swojej roli. Reguła tymczasowa z art. 112a-112d u.f.p. obejmuje jedynie część wydatków budżetu państwa, co zmniejsza jej skuteczność ${ }^{31}$, ponadto nie reaguje na przebieg cyklu gospodarczego i zwiększa negatywne oddziaływanie wahań koniunktury ${ }^{32}$. Projektowana reguła stabilizująca ma być wolna od wad swojej poprzedniczki, ale jej skuteczność będzie można ocenić po dłuższym czasie. Nie można więc w chwili obecnej jednoznacznie stwierdzić, czy jej ustanowienie rzeczywiście może zapobiec ciągłemu zwiększaniu deficytu budżetu państwa, czy ma ona jedynie uczynić zadość wymogom regulacji UE.

Również reguła z art. 86 ust. 1 pkt. 1 u.f.p. dotycząca progów zadłużenia nie wytrzymuje, jak się wydaje, zderzenia z rzeczywistością ekonomiczną, czego wyrazem jest czasowe zawieszenie jej stosowania, a w przyszłości być może całkowite jej uchylenie. Jednym z argumentów za jej zniesieniem jest niekorzystny wpływ ograniczenia deficytu na gospodarkę $^{33}$. Wydaje się więc, że główną konsekwencją zreformowania reguł wydatkowych będzie zniesienie pierwszego progu procedur ostrożnościowych i sanacyjnych, z którym związane rygory okazały się nie do wykonania.

31 T.M. Budzyński, Opinia o ustawie o zmianie ustawy o finansach publicznych..., s. 8.

32 Uzasadnienie do projektu ustawy z dnia 26 lipca 2013 r. o zmianie ustawy o finansach publicznych, s. 1 i n.

33 Tamże. 
Skuteczność reguł wydatkowych może być poddana w wątpliwość z uwagi na fakt, że nie obejmują one wszystkich wydatków budżetu państwa. Wydatki budżetu państwa wynikają z ustaw szczególnych, z których wynikają określone zadania państwa. Związane z nimi wydatki sztywne stanowią, jak wskazano powyżej, większą część wydatków budżetu państwa. Wprowadzanie ograniczeń wysokości wydatków w ustawie o finansach publicznych nie powinno dotyczyć tego rodzaju wydatków. Możliwość ich zmniejszenia zależy od wprowadzenia zmian w ustawach szczególnych. Wprowadzanie reguł wydatkowych do ustawy o finansach publicznych bez zmian ustaw szczególnych nie wystarczy do zmniejszenia wydatków budżetu państwa.

Prawidłowo skonstruowane reguły fiskalne, w tym wydatkowe, mogą stanowić użyteczny instrument planowania polityki budżetowej. Jednak aby spełniały swoją rolę, niezbędne jest ich przestrzeganie przez organy ustalające budżet. Obowiązek przestrzegania reguł wydaje się oczywistością, ale jak wynika z doświadczeń krajów, które je wprowadziły, głównie wtedy, gdy stosowanie reguły odbywa się bezboleśnie dla wydatków publicznych. Natomiast w sytuacji, gdy zastosowanie reguły pociąga za sobą koszty zarówno w sensie finansowym, jak i politycznym czy społecznym, dochodzić może do obchodzenia reguł, dzięki czemu stają się one pustą regulacją i są traktowane jako zbędne. Innym zjawiskiem jest modyfikacja reguł, która okazać się może łatwiejsza niż podołanie im. W obu przypadkach dochodzi jednak do zaprzeczenia sensu istnienia reguł, które są traktowane jako krępujący swobodę gorset lub regulacja o znaczeniu bardziej propagandowym niż realnym, a nie jako mechanizm mający zapewnić bezpieczeństwo finansów publicznych.

\section{Bibliografia:}

Budzyński T.M., Opinia o ustawie o zmianie ustawy o finansach publicznych oraz niektórych innych ustaw (druk senacki $n r$ 1062), Opinie i Ekspertyzy OE-159, grudzień 2010, http://ww2.senat.pl/k7/dok/opinia/2010/oe-159.pdf (dostęp: 19 września 2013 r.). 
Kantorowicz J., Reguły fiskalne - co się sprawdza?, [w:] Analiza FOR nr 3/2012, http://www.for.org.pl/pl/a/2067, Analiza-32012-Reguly-fiskalne-co-sie-sprawdza (dostęp: 13 września 2013 r.), s. 1-20.

Marchewka-Bartkowiak K., Reguły fiskalne, Analizy BAS nr 7/2010, s. 1-7.

Marchewka-Bartkowiak K., Zarzq̨dzanie długiem Skarbu Państwa. Implikacje dla strefy euro, Warszawa 2011. 